\title{
Transformations of the transport system of the city of Lublin as a city-forming factor. Part 1
}

\author{
Natalia Przesmycka \\ https://orcid.org/0000-0002-1755-2448 \\ n.przesmycka@pollub.pl \\ Department of Architecture and Urban Planning, Faculty of Civil Engineering \\ and Architecture, Lublin University of Technology
}

\begin{abstract}
Summary: Lublin is an example of a medium-sized city, whose urban layout was shaped to a large extent by the conditions resulting from changes in the transport system. The very emergence of the city - initially as a settlement complex located on the neighbouring hills - was associated with the travel and trade routes of supra-regional importance crossing the Lublin region. The historical communication system is still visible in the urban structure of the city. The paper presents the most important transformations of the communication structure of the city of Lublin from the beginning of its existence to the 1920s. The next part will deal with issues from the years 1931-2016.
\end{abstract}

Keywords: Lublin, urban planning in Lublin, historical communication network of Lublin, roads and streets of Lublin

\section{Introduction}

The spatial layout of the city of Lublin is characterized by its uneven development in different periods of time in the city's history. The mechanisms influencing it were primarily related to the economic importance and political situation of the city. Through most of its history: the Middle Ages, the later prosperity period of the $16^{\text {th }}$ century or the gradual economic decline from the $17^{\text {th }}$ century to the end of the $18^{\text {th }}$ century, the city did not see any significant territorial expansion. The situation changed in the $19^{\text {th }}$ century. The urban development of Lublin in the first years of the Russian partition was brought about by the growing political importance of the city as the capital of the province with a large Russian army garrison stationed there. The urban transformations of Lublin in the period 1815-1939 depended both on local as well as national and international aspects. Urban planning decisions taken during this period were subject to various factors such as the specific topographical conditions (the location of the city on the hills intersected by the valleys of three rivers), the complex ownership structure resulting from the existence of several dozen separate settlements within the city, as well as complex social and religious relations within the population.

As a result of the planning actions of the period in question, communication arteries, residential districts, industrial development zone and important municipal investments, which are of key importance for the urban shape of the present-day Lublin, were laid-out and later implemented. 


\section{Communication as a city-forming element}

\section{Trade settlements}

Transportation in antiquity and in the Middle Ages was based mainly on water transport routes. Hence, urban centres which had access to the sea or rivers suitable for sailing or floating developed first. In such cases, waterfronts and port areas very often took on the role of the most important public spaces with their dominating trade function. In the case of cities that were located far from the waterway access that allowed goods to be transported ${ }^{1}$, settlements developed in places where land transport routes split or crossed, and sometimes in places where travellers stopped on a longer route, which had to be additionally have favourable natural environmental conditions. In the case of market settlements, the location near an important and frequented transport route was the basic urban-forming factor. On the territory of today's Poland, this factor played a crucial role mainly in the settlements established in the $11^{\text {th }}-12^{\text {th }}$ century (after the period of decline in the development of the town and their function). Many trade settlements developed into urban centres - linking their urban layout with the structure of original foundation towns in a variety of ways. Analyzing this process the following process outlines can be distinguished:

- Preservation of the spatial layout of the commercial settlement by excluding it from the city's charter. In such case this settlement usually formed a city's suburb

- Inclusion of the spatial layout of a commercial settlement in the layout of the charter city. Depending on the size and shape of the settlement, it was possible to entirely or partially adapt its layout to the location boundaries of the city. Large trade settlements with large internal squares could become cities in their entirety once they were surrounded by city walls, the market was establishment and the plot layout was regulated, while smaller settlements were sometimes included in the regulated urban layout of the city's charter.

In most cases of trade settlements, urban layout formed along the existing transport routes. The role of the market was often taken over by the extended part of the main street, which was at the same time a section of a trade route or a local road, cutting through a banded, transverse arrangement of plots of land ${ }^{2}$.

\section{The oldest roads and tracts in Lublin}

When discussing the communication system of medieval Lublin in the pre-charter period, one should pay attention to the particular natural conditions determining the development of the settlement. The existence of two very different geographical regions - northern woodland and southern agricultural land - was the reason behind the emergence of trade in this area. The Czechówka River flowing into Bystrzyca River formed a swampy wetland prone to flooding. In the early Middle Ages, the original Czechówka riverbed was located near the escarpment of the Old Town Hill, while Bystrzyca was running at the foot of the escarpment of Podwale. The topographical layout was dominated by hills, which guaranteed a comfortable observation spot increasing the settlement's safety. Equally attractive were the fringe areas of the upland (tip of the upland embankment), which were crossed by communication routes. The first settlement was established on the following hills: Czwartek, Grodzisko and Białkowska Góra. At the turn of the $7^{\text {th }}$ and $8^{\text {th }}$ century settlements also appeared on the Old Town and Castle hills, and perhaps also on Żmigród. The earlier communication system shaped the urban form of market-centred settlements and influenced the development of the location city. At the turn of the $11^{\text {th }}$ and $12^{\text {th }}$ centuries, the population grew, and by the beginning of the $12^{\text {th }}$ century, the shape of a pre-location town

1 In Poland there are a number of places whose names refer to the tradition of weekly fairs on specific days of the week, e.g. Saturday, Wednesday or Thursday.

2 A. Berdecka, Lokacje i zagospodarowanie miast królewskich w Małopolsce za Kazmierza Wielkiego (1333-1370), W-wa, Kraków, Gdańsk Łódź, Zakład Narodowy im. Ossolińskich. Wydawnictwo PAN, 1982, s. 94-95. 
(a market settlement on Czwartek, a settlement on the Old Town and a governor's stronghold on Castle hills) became established.

In the $8^{\text {th }}$ to $9^{\text {th }}$ century Lublin was already a relatively large settlement centre in the region. In the pre-Christian period, the buildings formed a dense belt of open settlement situated by the communication route towards the Bystrzyca River crossing. In the $10^{\text {th }}$ century, a church dedicated to St. Nicholas was built on Czwartek Hill, commonly considered to be the oldest church in Lublin.

In the first half of the $10^{\text {th }}$ century, a settlement on the Old Town Hill near St. Michael's Church became a new centre of Lublin. Researchers believe the location of the temple to be a former place of pagan worship.

During the $12^{\text {th }}$ century, the castle was relocated from Grodzisko Hill to Castle Hill. Since the Castle Hill had better defensive qualities than Grodzisko Hill. It was located among the wetlands formed by the flooding waters of Czechówka and Bystrzyca rivers. The most important trade and communication routes of the time met at the foot of the hill, leading in directions of Sieciechów, Sandomierz, Ruthenia and Łuków ${ }^{3}$.

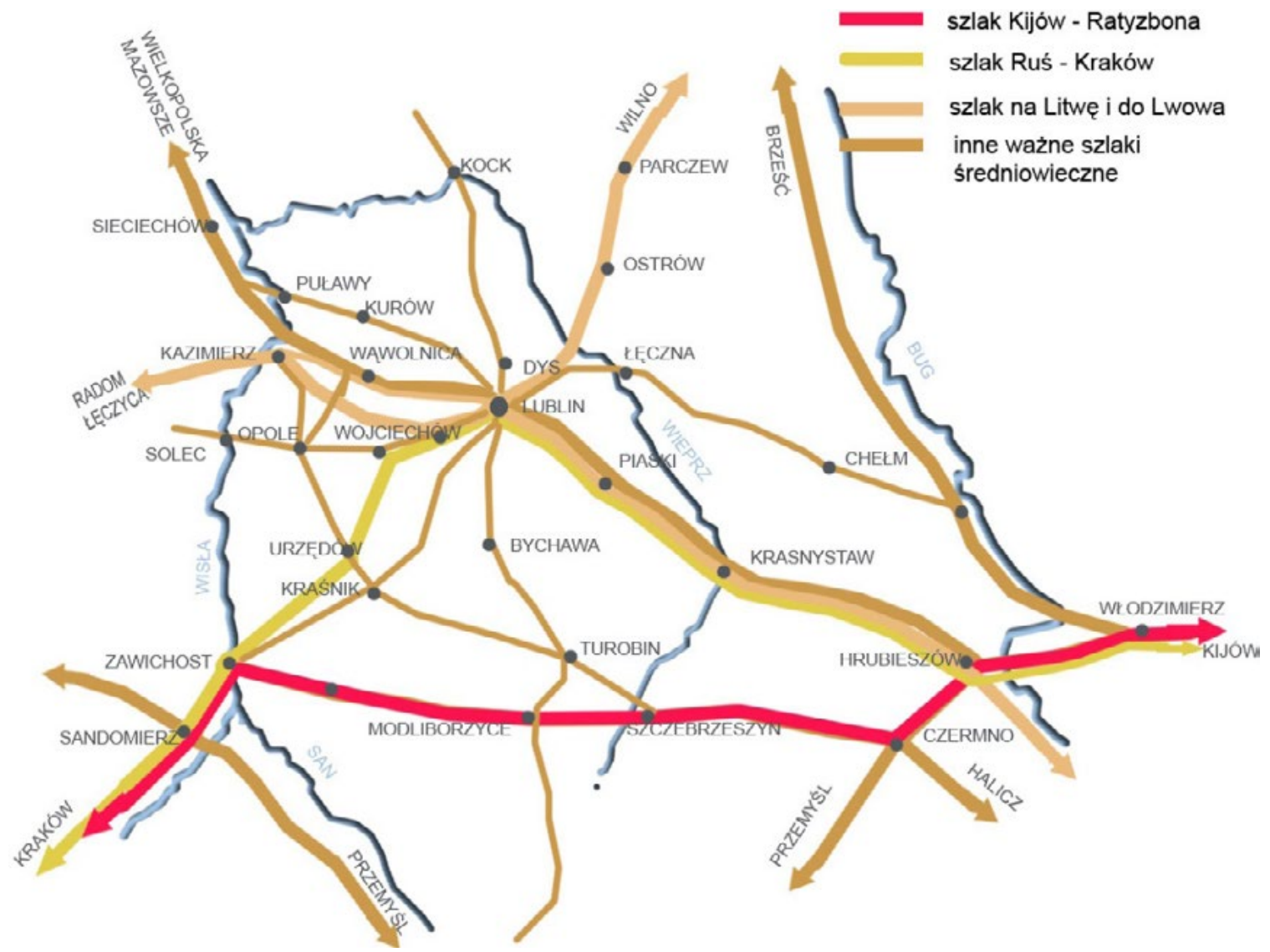

Fig. 1. Road network diagram of the Lublin region in the Middle Ages. Author: Natalia Przesmycka

In the urban layout of contemporary Lublin, several structures from the pre-localisation period can be observed, which shape was determined by the earlier communication system. The most visible are the urban structures of open settlements, emerging in the northern part of the medieval settlement system, today they are located in the inner-city: Czwartek and Kalinowszczyzna. Czwartek is considered to be the oldest settlement within the urban complex in the area of the present-day Lublin. The name itself indicates its commercial

3 The time of establishing the castle as an administrative and economic centre, which would also be a convenient defensive point, is defined at the beginning of the second half of the $12^{\text {th }}$ century, when Duke Henryk Sandomierski returned from the Crusade and the Sandomierz Province was separated from the Crusade. It is believed that in the beginning of the $13^{\text {th }}$ century at the latest, the town administration was transformed into a castellan administration. Za: A. Rozwałka, R. Niedźwiadek, M. Stasiak, Lublin wczesnośredniowieczny, Wyd. Trio, Lublin 2006, p. 99-102. 
origins. Settlement developed by the communication route running along the edge of the Czechówka River valley upland, and connecting with the route leading south-east (passing through the Old Town Hill and leading further to Lesser Poland region - present-day Małopolska). Located in the highest part of the settlement, the Church of St. Nicholas was probably the oldest Christian church in Lublin.

Kalinowszczyzna (Słomiany Rynek - Hay Market). This is an example of a trade settlement in the form of a fork. Transport routes splitting in the vicinity of the ford on Bystrzyca River in the direction of Ruthenia and Lithuania have created a convenient place for the development of local agricultural products trade. With time, local trade became specialised in grain and cattle, hence the name Słomiany Rynek (Hay Market). The subsequent housing development along the Towarowa and Kalinowszczyzna Streets had preserved the course of medieval communication routes.

\section{Urban Charter}

The granting of urban charters to Polish cities in the $13^{\text {th }}-14^{\text {th }}$ century was usually involved the regulation of their existing spatial layout. Most often the city was planned on a rectangular, regular street layout with a centrally located square. In the case of Lublin, the layout of the city did not follow any regular geometrical pattern, the arched curves of the market square frontage and streets were adjusted to the terrain's morphology and most probably to the existing earlier housing development of the hill. At present, it is believed that the urban planning of the Old Town Hill is the effect of the urban charter being granted in two stages. ${ }^{4}$

In 1317 Władysław Łokietek ordered Maciej, the mayor of Opatów, to grant the charter to the city of Lublin and conferred 100 fields of cultivated and uncultivated land to the city as measured according to Magdeburg law. This act excluded the city from the authority of the Lublin Governor and the Sandomierz Voivode. The charter most probably fixed the previous shape of the pre-charter settlement, which stretched on both sides of the communication route towards Małopolska - along the line of today's Grodzka Street. The layout of the city does not assume a regular geometrical pattern due to natural conditions. The arrangement of the city from the period of the second stage of granting the charter is based on the chessboard planwhich was flexibly adapted to the configuration of the Old Town Hill and its pre-existing buildings. Certain compositional coherence is visible in the urban arrangement between the city and the castle along the Grodzka Street, analoguous with the layout of Cracow and the Wawel Castle. ${ }^{5}$

The Lublin market was laid-out in the form of a trapezoid, with curved sides, measuring $62 \times 72$ metres. The arc-shaped deflection of Złota and Rybna Streets probably resulted from the existing remnants of defensive fortifications, from the time of the pre-charter town settlement. Złota Street leading to the monastery and Dominican church is 9 metres wide. Similarly, Grodzka Street's variable width also reaches 9 metres. Other residential streets - Olejna, Archidiakońska and Jezuicka were 6-7 m wide.

\section{Housing development outside the city walls}

From the early Middle Ages Lublin functioned as a complex of several settlements. The fortified charter city existed in the vicinity of other settlements: the former market settlement by the Czwartek Hill, a settlement in the area of the present Kalinowszczyzna and clusters of buildings along the main communication routes. According to $\mathrm{Cz}$. Gawdzik, church locations took place in areas that had already been settled before. ${ }^{6}$

With the development of settlement outside the city walls in the $14^{\text {th }}$ and $15^{\text {th }}$ centuries, Lublin suburbs developed. The development took place in two directions:

4 The first layout of the city took the form of a street and stripes. It did not include the southern and western parts of the Old Town Hill and the part belonging to the Church - along the eastern edge of the Old Town slope. On the south-western side of its border there was the current line of Hartwigów, Rybna and Złota Streets - a former line after the fortifications of the castle from the tribal period. Ibid., p. 147.

5 T. Tołwiński, Urbanistyka, T. 1, Warsaw 1939, p. 147.

6 Cz. Gawdzik, Rozwój urbanistyczny Starego Lublina, Ochrona Zabytków, 7 (3)/26, 1954, p. 148 
North-eastern - along the route to Ruthenia, forming the suburbs of Czwartek, Podzamcze and Kalinowszczyzna. The oldest continuous open settlement existed there;

Western - part of the city, on the outskirts, where the following church and monastery locations: The Holy Spirit Church, Bridgettine Order monastery and The Cistercians monastery became the elements crystallising the urban layout. As a result, the Krakowskie Przedmieście formed.

Outside the city walls, in the Middle Ages, several residential colonies of immigrant populations were established. The Ruthenian people, who probably came with merchants from Ruthenia, settled on the southern side of the suburbs of Czwartek ${ }^{7}$. A vibrant Jewish community started settling in Podzamcze area in the first half of the $14^{\text {th }}$ century.

\section{Communication system of Lublin until the end of XVIII century}

Since 1532 Lublin has been the venue for local nobility assemblies of the Lublin Voivodeship, and since 1543 Lublin has been the venue for general assemblies. The growing political importance of Lublin led to the establishment of the Main Crown Tribunal for Lesser Poland in 1578. This event had a major impact on the economic and urban development of the city and its suburbs. At the same time as the economic and political significance of the nobility grew, the importance of the bourgeoisie was decreasing. In 1550, the law allowed the nobility to invest in construction and do business in urban areas. Thus, the period of noble democracy in Poland coincided with the economic collapse of many urban centres, which began to lose their privileges. Despite purchasing real estate located in the city, the nobility did not want to bear the burden of urban law and be subject to urban jurisdiction. The so called "libertations" were the legal sanction of removing private land from the city's authority. With time "jurydyki" (separate jurisdictions for nobility, clergy and royalty) began to be established in the city. The political and economic role of the bourgeoisie has weakened in favour of the nobility and the magnates.

Until the $18^{\text {th }}$ century, the road network shaping Lublin's urban layout had an outstandingly reconstructive character and ran along to the most convenient terrain. The transport system of the city, shaped in the $16^{\text {th }}-$ $17^{\text {th }}$ century, was the result of the consolidation of earlier routes and the growing importance of new directions of transport (e.g. route to Zamość). Secondary streets were most often developed from small access roads leading to premises within the boundaries of ownership divisions.

From the sixteenth to the eighteenth century the main communication route (East-West), still ran through the city within its walls. In the west it was Krakowskie Przedmieście Street, the trail ran through Grodzka Street, Market Square, St. Michael's Church, through the Grodzka Gate, Szeroka Street in the direction of Podzamcze Suburb, where it forked to the north and east, i.e. to Lithuania and Ruthenia. Krakowskie Przedmieście Street was a fragment of the route to Cracow and Warsaw, which from the $16^{\text {th }}$ century took over this function from the older Cracow route, which ran along today's Narutowicz and Kozia Streets. The route towards Warsaw led through Dominican fields and Wieniawa. It branched out in the vicinity of the Church of the Holy Cross in the direction of Cracow.

At the end of the $16^{\text {th }}$ and $17^{\text {th }}$ centuries, apart from the road layout, the elements which had the most impact on shaping the urban layout developing outside the city walls were monasteries and church assumptions, constituting a kind of "islands" in the fabric of suburbs ${ }^{8}$. Due to their dominant size over the surrounding buildings, they quickly became landmark and identification points of the surrounding area. Their location often determined further directions of housing development, grouped by the adjacent communication routes, and in respect to the ownership boundaries of land. The range of residential function areas has undergone significant changes since the $16^{\text {th }}$ century. In the suburbs, magnate residences and noble manors appeared. Some of

7 The first mention of the Lublin Orthodox Church comes from a document from 1390 and testifies to the then existing in Lublin temple and religious life centre in the Eastern rite. The next one, from 1447, talks about the foundation of the Spas Church "at Słomianym Rynek" by Princess Maria Ivanova of Kiev. After: G. Kuprianowicz, M. Roszczenko, Cerkiew Prawosławna Przemienienia Pańskiego w Lublinie, Lublin 1993, p. 11,14. Probably the church was built on a hill, near the road to Ruthenia and Lithuania. Near the church there was a market square for grain or animals, hence the name of Słomiany Rynek (Hay Market), which appears in documents.

8 In the first half of the $17^{\text {th }}$ century 11 new church and monastery foundations were established, which performed religious, cultural, manufacturing (mostly for own needs), care, education and housing functions. 
them were fortified, however this changed over time and these residences became more and more residential. Until the $18^{\text {th }}$ century, only the Old Town Hill and Krakowskie Przedmieście were dominated by compact brick buildings. In the suburbs of Czwartek, Kalinowszczyzna, Podzamcze and the surrounding settlements buildings were still mostly wooden. The building development in the immediate vicinity of the river valleys and the Castle Hill (the Jewish town) was gradually becoming denser.

In the $17^{\text {th }}$ century the river valleys underwent significant transformations. Under the influence of human activity and climate change, the floodplains of Bystrzyca, Czechówka and Czerniejówka ${ }^{9}$ rivers began to gradually dry out. The Great Royal Pond was reduced, leaving behind wet meadows and swamps. In the sixteenth and seventeenth centuries levees with added communication capacity were built.

Urban transformations during the $16^{\text {th }}$ and $17^{\text {th }}$ centuries led to the development of the main elements of the current city's structure. The development of new buildings was adjusted to the natural conditions and ownership relations. In the sixteenth and seventeenth centuries a street network developed, which stood in a slightly modified form until the early twentieth century. In the $16^{\text {th }}$ century the following street names of appear on the map: Kowalska and Żydowska (1598); in the $17^{\text {th }}$ century Dyska (1601), Szeroka (1622), Zasrana Brama (1626), Podzamcze (1626) and Podwale $(1683)^{10}$.

Particular phases of construction development were limited and determined by the presence of fortification lines and ramparts. At the turn of the $18^{\text {th }}$ and $19^{\text {th }}$ century, the city walls were almost completely absorbed by the developing residential areas. The last noticeable remains of seventeenth-century fortifications and ramparts currently follow the line of present-day Lipowa Street.

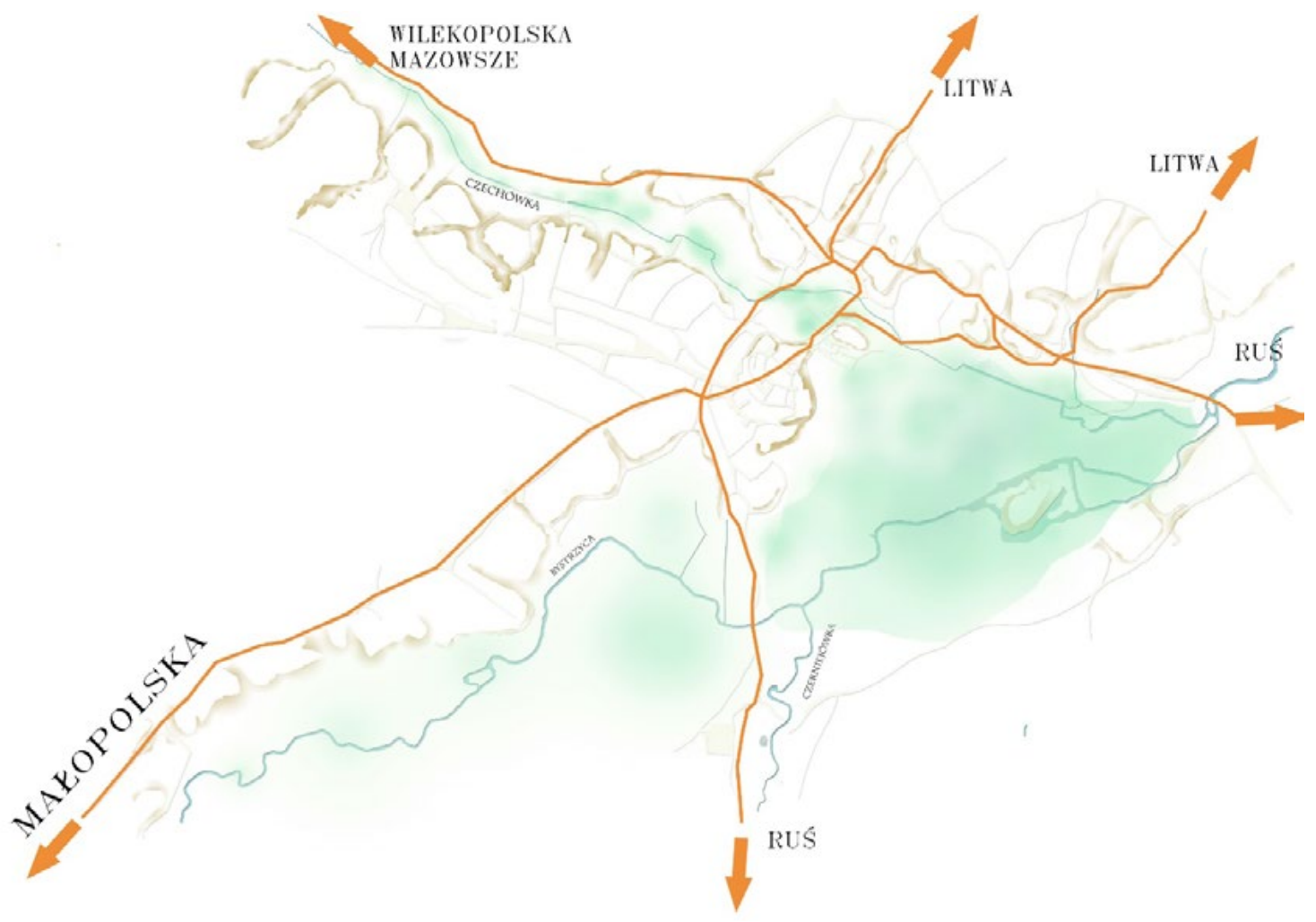

Fig. 2. The road network diagram in the Lublin area against the background of the local topography of the $12^{\text {th }}-13^{\text {th }}$ century. Author: Natalia Przesmycka 


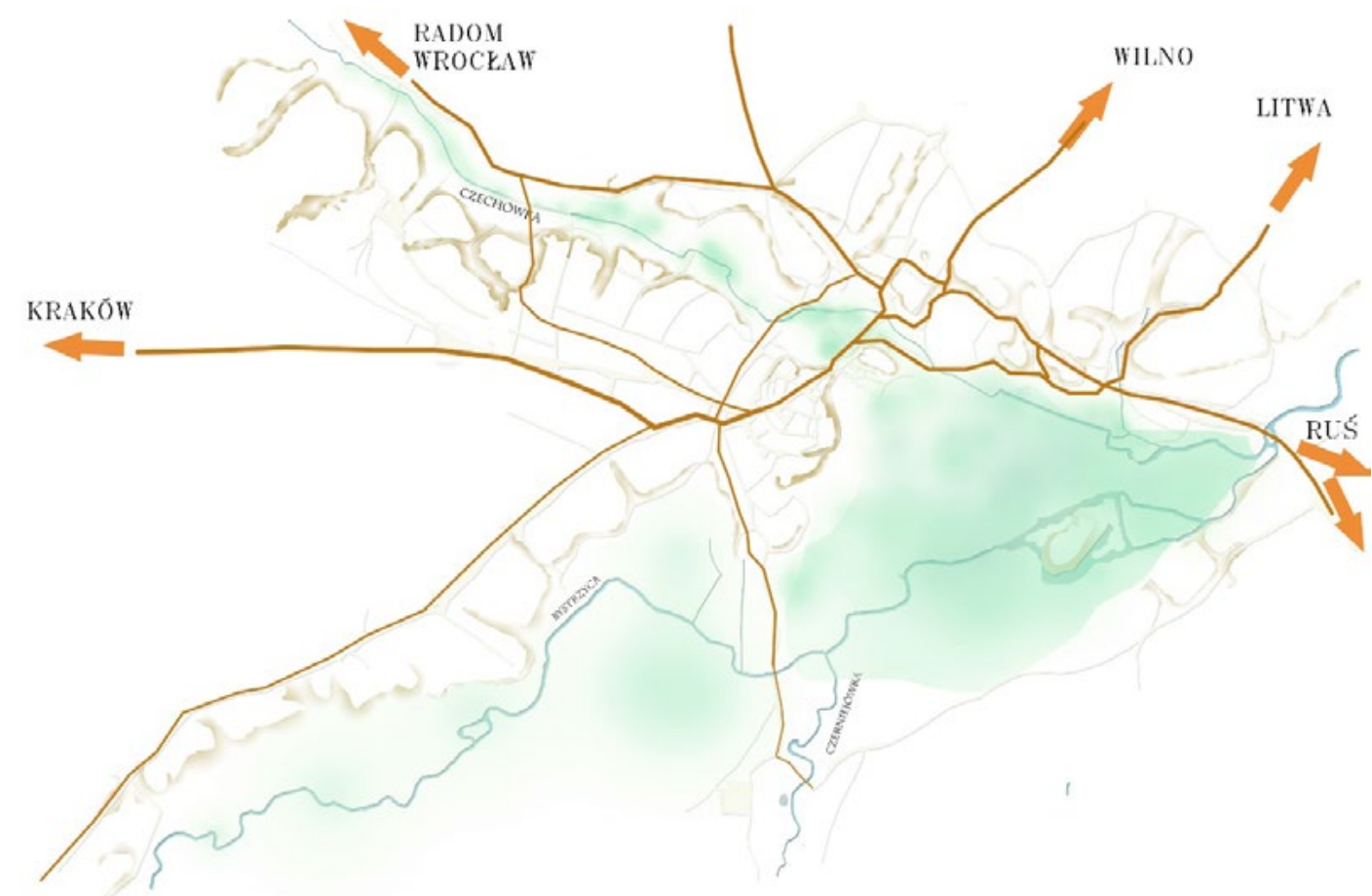

Fig. 3. The road network diagram in the Lublin area against the background of the local topography of the $14^{\text {th }}-15^{\text {th }}$ century. Author: Natalia Przesmycka

\section{The restructuring of the Lublin communication system in the XIX century}

In the first years of the Kingdom of Poland, Lublin, which became the next largest city in the Kingdom (after Warsaw), was abandoned, ruined and with poor sanitary conditions. After the establishment of the Zamość fortress, it became an important transport hub between the Kingdom and Russia, gaining military and political importance. The 1830s was a period of fundamental change in the appearance of the city, often referred to as the "second rebirth of Lublin". It was then that the city's transport system underwent fundamental transformations. In the $19^{\text {th }}$ century, for the first time in a planned manner, new streets were laid-out and the existing ones were regulated.

After 1815 the western side of Lublin's trenches were renovated, along the lines of the former city ramparts, thus making it impossible to reach the city without police control. In 1818, the city tollgates (Warsaw, Lubartów and Zamość) were established. These tollgates protected the interests of the treasury and the city, but did not determine its administrative limits. Outside the tollgates, but within the administrative limits there were suburbs of Piaski and Czwartek, and within the boundaries of "consumption embankments" there was a village and Rury farm, which at that time was a separate rural commune. The only entrance to the city without the tollgate was from the side of the village of Rury, because it was only of local significance for villagers to enter into the city. As a result, the former communication route towards Małopolska has lost its importance ${ }^{11}$. 


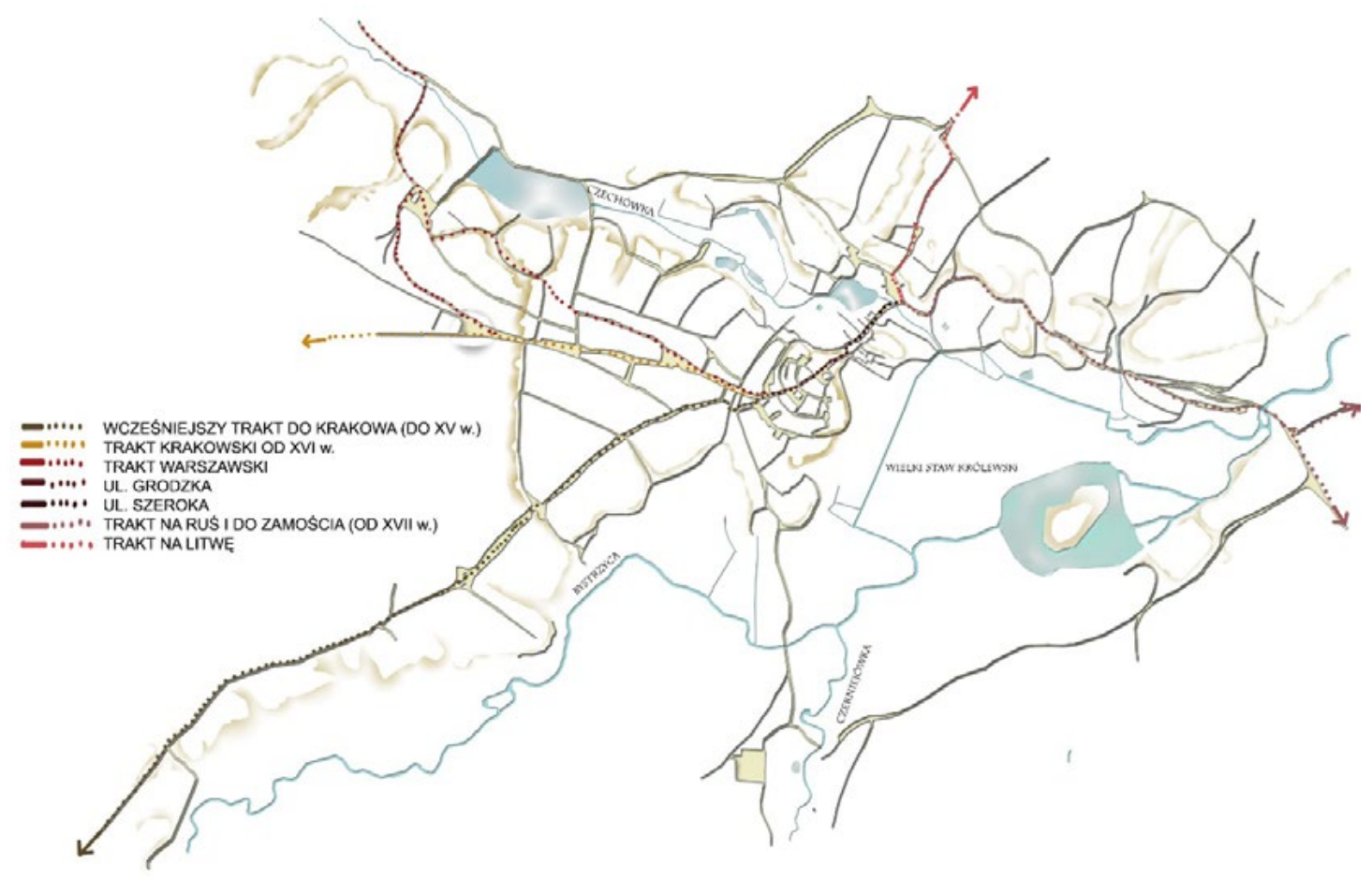

Fig. 4. The road network diagram in the Lublin area against the background of the local topography at the beginning of the $19^{\text {th }}$ century. Author: Natalia Przesmycka

Reconstruction of the city in the period 1815-1830 was mainly associated with setting new communication routes: Warsaw, Lubartów and Zamość, as well as with the creation of new town squares: cathedral, Town Hall (Łokietka), Drill (Lithuanian) and Bernardyński (Wolności).

As a result of the reconstruction, the Old Town remained on the sideline of communication routes. All three main routes converged in front of the Cracow Gate. Since then the city centre has moved in the direction of Krakowskie Przedmieście ${ }^{12}$. The new Warsaw route was built as the extension of Krakowskie Przedmieście, bypassing the existing road running thorough the towns of Wieniawa and Snopków.

The most important change in the transport system, which affected the future urban shape of the city, was the establishment of the Zamość route. The Zamość route was set along the former Korce Street (today Królewska Street). In 1818 the buildings of the former Jesuit college, destroyed during the fire of 1803, were demolished. Only the northern wing, adjacent to the Trinitarian gate, remained. After the area was levelled, it became possible to arrange a representative square in this place, its spatial frames were determined by: the building of the cathedral church, the building of the college and the Trinitarian tower dominating over them (erected in 1819 on the site of the former gate in the city walls). The collected rubble was formed into a mound, on which a new street ran next to the cathedral church and missionary buildings (present-day theological seminary). Material from the ruined castle was also used for these works. In this way a monumental Cathedral Square was created, which at that time performed communication and representative functions, and the Trinitarian tower became a new dominant in the panorama of the Old Town Hill. The road ran along the cobbled route to Bystrzyca River, where a new brick bridge was built ${ }^{13}$. This road was finally completed in 1826.

12 A similar situation took place in other Polish cities, e.g. in Warsaw, where the Old Town, while remaining on the sideline of the developing city, gradually declined. 
At the beginning of the $19^{\text {th }}$ century, the Drill Square was created ${ }^{14}$. It was the first public square in Lublin for non-trade purposes. Variety shows and military parades, as well as demonstrations of drill exercises were performed in this new square, attracting crowds of citizens and visitors. This was in line with the contemporary trend for spending free time and providing entertainment for the masses (modelled after the Saski Square in Warsaw), and was combined with the desire to highlight the leading political forces in the city space. In 1819, at the order of the Imperial Governor, General Prince Joseph Zajączek, a new drill square was arranged in the empty area created after the demolition of the ruins of the church and hospital of the Brothers Hospitallers of St. John of God and the surrounding buildings. The creation of the new square led to the final decision on the course of the new Warsaw route - by extending of Krakowskie Przedmieście Street. Thus, the narrow and winding road leading through Wieniawa and splitting in the vicinity of the remains of the Monastery of St. John of God ceased to be important. The square "at the crossroads" ceased to exist as well, and the first modern, consciously composed urban city interior - the present Lithuanian Square - was created.

The communication system also entailed the regulation of the new functional division of the area. Interestingly, the first demarcated zone of general urban importance was the cemetery. The location of the municipal cemetery on Rury (the land located on the western side of the city trenches) was crucial for the city's spatial development in the western direction. The beginning of the functioning of the cemetery dates back to October 1811. In 1829 burials at the old Jewish cemetery (the Jewish cemetery on Grodzisko Hill) ceased and a new Jewish cemetery was established next to the exit road from Lublin to the north, located near the Orthodox cemetery (extension of Nowa and Lubartowska Streets) ${ }^{15}$.

In the first years of the Kingdom of Poland development was concentrated in the area of Krakowskie Przedmieście, which was a continuation of Lublin's urban growth towards the west, which had been going on since the Middle Ages. Single and two-storey brick tenement houses with adjacent annexes were erected instead of the former single-storey wooden houses. Side offices reached deep into the back of the plot and rear outbuildings were also created, so that with time the courtyards closed completely. Nowa Street, today's Lubartowska Street, marked a new direction of residential development in the centre of Lublin, starting from the 1840s and 1800s.

In the middle of the $19^{\text {th }}$ century, the city began to lack land plots suitable for residential construction. In the western part of the city, on the northern side of the Warsaw route, there was a city garden, while the southern side was intended for the army use in the future ${ }^{16}$. The development of buildings in this part of the city was also blocked by the areas designated for the municipal cemetery and the buildings of the Wieniawa town adjacent to Lublin. In this situation, the city tried to incorporate into its area land plots previously used for agricultural purposes.

\section{The transport system in the Jewish Town}

In 1825 , the Jewish population constituted $54.4 \%$ of the town's population. The Jews, according to royal privileges de non tolerandis Judaeis, could only live in certain districts and had no right to purchase or lease property in Christian parts of city. In spite of this, Jews often built on contested land adjacent to Christian population. In the northern part of the town on Czwartek and around the Castle Hill an area called the Jewish Town has

14 The first drill square was arranged near the Warsaw route, in the vicinity of the "Świętokrzyskie" barracks. Next, the parades were carried out on Krakowskie Przedmieście Street near the present Lithuanian Square. Since the surface of the street was made of field stones, the so-called "cats' heads", the street turned out to be unsuitable for this purpose. N. Przesmycka, Lublin..., op.cit., p.

15 Mikulec B., Aktywność gospodarcze ludności żydowskiej Lublina w latach 1815 - 1864, [in:] Żydzi w Lublinie, Lublin 1995 , p. 70.

16 The presence of military garrisons of occupying forces stationed in Lublin initially influenced the urban shape of the city during the time of Austrian Partition (1794 - 1805). The area adjacent to the Świętokrzyskie barracks, situated by the Warsaw road, became the property of the army in 1858. This area was customarily called the Western Camp. Other extensive military areas were located on the southern side of Lublin, outside the city's administrative borders, in the vicinity of the railway line - the so-called South Camp. 
developed, inhabited since the $15^{\text {th }}$ century. Within this area, the poorest housing conditions could be found in the Podzamcze area, a former prefect's jurisdiction, stretching around the Castle Hill ${ }^{17}$.

The Jewish town was characterized by its organic layout of streets, the oldest of which was Szeroka Street. The street was a part of an early medieval communication route running through the Castle Hill towards the settlement of Czwartek and the ford on Bystrzyca River. It gained the status of a local market and, with time, a shopping street. It was the first street in this part of the city with a paved surface (1815-1830). Another street of commercial importance was Ruska (paved after 1837). As the buildings grew, streets were formed at the foot of the Castle Hill: Krawiecka and Jateczna. Their names referred to the dominant activities of the inhabitants in these areas. Properties along the larger communication routes could be accessed by means of perpendicularly branching roads. Attempts at regulating the road system of the Jewish Town begin with the establishment of Nowa Street (1815-1830) and parallel streets towards Szeroka Street. The communication system in this part of the city was complemented by bridges connecting the two banks of the Czechówka River.

\section{Transport system in the centre of Lublin in the years 1864-1914}

In the second half of the $19^{\text {th }}$ century saw the first clear functional divisions appearing in the spatial structure of Lublin. Lublin, like most of the cities of the Russian Partition, suffered from the lack of adequate technical and sanitary infrastructure, which was severely affecting the population in the face of increasing density of buildings caused by the rapid rise in the number of inhabitants. The answer, at the time, to bad sanitary conditions was to establish public gardens and green areas, and to establish strict building and housekeeping regulations. The issues of street layout regulation, especially in the inner city area, were crucial for the proper shaping of buildings and public spaces. For Lublin, the years 1864-1914 were a time of significant spatial transformations, which shaped the city's new image.

The directions of urban development of Lublin in the middle of the $19^{\text {th }}$ century, apart from ownership status, began to be determined by new industrial investments and infrastructure. Industrial plants, initially built in a spontaneously, adopting abandoned buildings (e.g. monasteries), or located in the centre, after the construction of the railway line, began to be moved and erected in the southern part of the city. Thus, the railway (from 1877) became a new urban development factor.

In the 1860 s, the need to redefine the administrative city limits and city's areas emerged. In the $1870 \mathrm{~s} \mathrm{Lu-}$ blin became the third largest city in the Kingdom of Poland with a population of 29,000. The transport system together with the public areas and urban greenery (both the arranged and natural ones, interconnected with watercourses), created a framework for the development of buildings at the turn of the $19^{\text {th }}$ and $20^{\text {th }}$ centuries. The urban layout, shaped in the years 1864-1914, has survived to this day in an essentially unchanged form, becoming the basic structure of the city centre of Lublin.

At the turn of the nineteenth and twentieth century, Lublin's buildings developed along the main routes of national importance: west towards Warsaw, south to Zamość, and north, along the route of regional importance towards Lubartów. Industrial investments developed along the railway line. The greenery formed a banded system linked with river valleys. Along the Czechówka River, despite technical and sanitary problems, substandard residential buildings developed intensively.

The transport system of the city centre and the northern part of Lublin in the years 1864-1914 became denser and more complete in comparison to the previous period, but its basic framework did not change. The most important street in the city and its communication axis was still Krakowskie Przedmieście. All of important state offices were concentrated in Krakowskie Przedmieście Street. In search of new building areas in the city centre new streets were marked out at the end of the $19^{\text {th }}$ century: Ogrodowa (1883), Szopena (1892-1908), Sądowa (1894), and Hipoteczna (1895), and just before the outbreak of World War I: Krótka, Zielona, Czysta and

17 In 1822 Jewish districts were introduced in the cities of the Kingdom of Poland, and in 1836 those who were granted the right to live outside the district were forbidden to run more than one shop. B. Mikulec, Aktywność...., op. cit. Podzamcze area was developed in a dense and chaotic manner. This area became habitable as a result of a decrease in the level of groundwater, but it still consisted of marsh and peat land. The concentration of buildings on a small area was so great that it did not allow for the construction of toilets or garbage bins, not even a shared one between a few houses. Podzamcze area was additionally exposed to the runoff of wastewater from the Old Town and Czwartek Hills and from the municipal slaughterhouse located on the left side of the Czechówka River. 
Cicha streets. Streets were also laid-out between parcelled areas and existing transport routes. More new streets were planned in the south of the city due to the location of the railway station and southern industrial district.

A characteristic feature of Lublin is the differentiation of the course of streets. In the part of the city centre delimited from the west by a line of trenches, they had an organic course, adapting to the terrain and previous administrative and ownership divisions. Due to the specific, rich terrain only few of the newly marked out streets had a straight course (e.g. Nowa Street, Zamość Route, Warsaw Route, Foksal). On the other hand, thanks to a less diverse terrain, the newly marked out streets in the southern part of the developing city - in the industrial district - were straight. This arrangement helped to ensure the most rational and economic manner of dividing land into building plots.

Gradually, the street network in the city centre was paved and renovated. Pedestrian traffic was improved with paved sidewalks made of stone slabs, bricks and asphalt (since the 1860s). The streets did not have sewers and storm canals. They were equipped with deep gutters or ditches covered with wooden bridges.

New transport routes of importance for the whole city were created as a result of the need to connect the train station located in the Piaski suburb with the city centre. In 1875 (i.e. 2 years before the opening of the railway), a new street called Foksal (now May $1^{\text {st }}$ Street) was established, reaching Zamojska Street, connecting the railway station with the city ${ }^{18}$.

In 1899 regulation works were carried out on Cmentarna Street, levelling the former ramparts, thus creating a "boulevard for funeral processions"19. The newly created street (present-day Lipowa Street) has preserved in its shape the course of the the $17^{\text {th }}$ century fortification lines, with characteristic triangular squares free of buildings in place of the former bastions. The only preserved bastion is located in the Saski Garden Park, while the squares are visible next to the building of Secondary School No 29, in front of the cemetery and at the intersection of Lipowa and Narutowicz Streets.

At the beginning of the $20^{\text {th }}$ century several new bridges were built in Lublin. The first reinforced concrete bridge was erected on the Czechówka River on Lubartowska Street, another one over Bystrzyca River by the road in the direction of Łęczna $(1908)^{20}$ and at Zamojska Street (1909), connecting the city with the railway station and roads in the direction of Zamość and Bychawa. The latter two replaced the old wooden ones, which were no longer able to handle the increased traffic. The neo-Gothic bridge over Bystrzyca on Zamojska Street, built in 1909, is particularly interesting in terms of its architectural form ${ }^{21}$.

The regulations of the transport system were also applied to the zone of the strict city centre - the vicinity of the Lithuanian Square. In 1876 an Orthodox Church cathedral was erected opposite the government building. This has increased the importance of the square as a place of political significance. The new arrangement of the square was designed by the Warsaw city planner Zygmunt Kisielewski, dividing the square with alleys into three parts. Each of them a greenery, arranged in calligraphic style ${ }^{22}$. The project was not entirely implemented, but the division of the interior and the idea of establishing greeneries were maintained. The garden in front of the governor's palace, together with the monument of the Union of Lublin, was separated from the space of the square with a wooden fence, while the greenery was surrounded with barriers ${ }^{23}$.

Before 1875, in order to widen the Krakowskie Przedmieście Street, the wall surrounding the Capuchin monastery was demolished, and later a part of Lithuanian Square (1900) was turned into a street. After the wall was demolished, the street was extended to the line of the church buildings, which finally cleaned up the space around the monastery. The Victoria Hotel was built on a parcelled post-monastery plot. Other buildings - two and three-storey tenement houses with shops on the ground floor, were erected at the end of the 1870s in the vicinity of the post office building, completing the southern frontage of the square.

\footnotetext{
18 Kierek A., Rozwój gospodarczy Lublina w latach 1918-1939, [in:] Dzieje Lublina, Volume II, edited by S. Krzykały, Lublin 1975, pp. 181- 182.

19 Ilustrowany przewodnik po Lublinie utożony przez Marię Antoninę hr. Ronikerowa, Warszawa 1901, p. 214.

20 Gazda L., Karaś S., Inż. Lutosławski i jego mosty w Lublinie, Drogownictwo, no. 2/2004, Warsaw.

21 Żywicki J., Architektura neogotycka na Lubelszczyźnie, Lublin 1998.

22 Ciołek G., Ogrody Lublina w XIX wieku, Ochrona Zabytków, rok 7, Warsaw 1954, nr 4, p. 270.

23 Gawarecki H., Stanisław Krzesiński: Dwa wrażenia, czyli Lublin jak był w roku 1827 i jaki jest w roku 1877, [w:] Rocznik Lubelski, R. I, 1958, Lublin, p. 246
} 


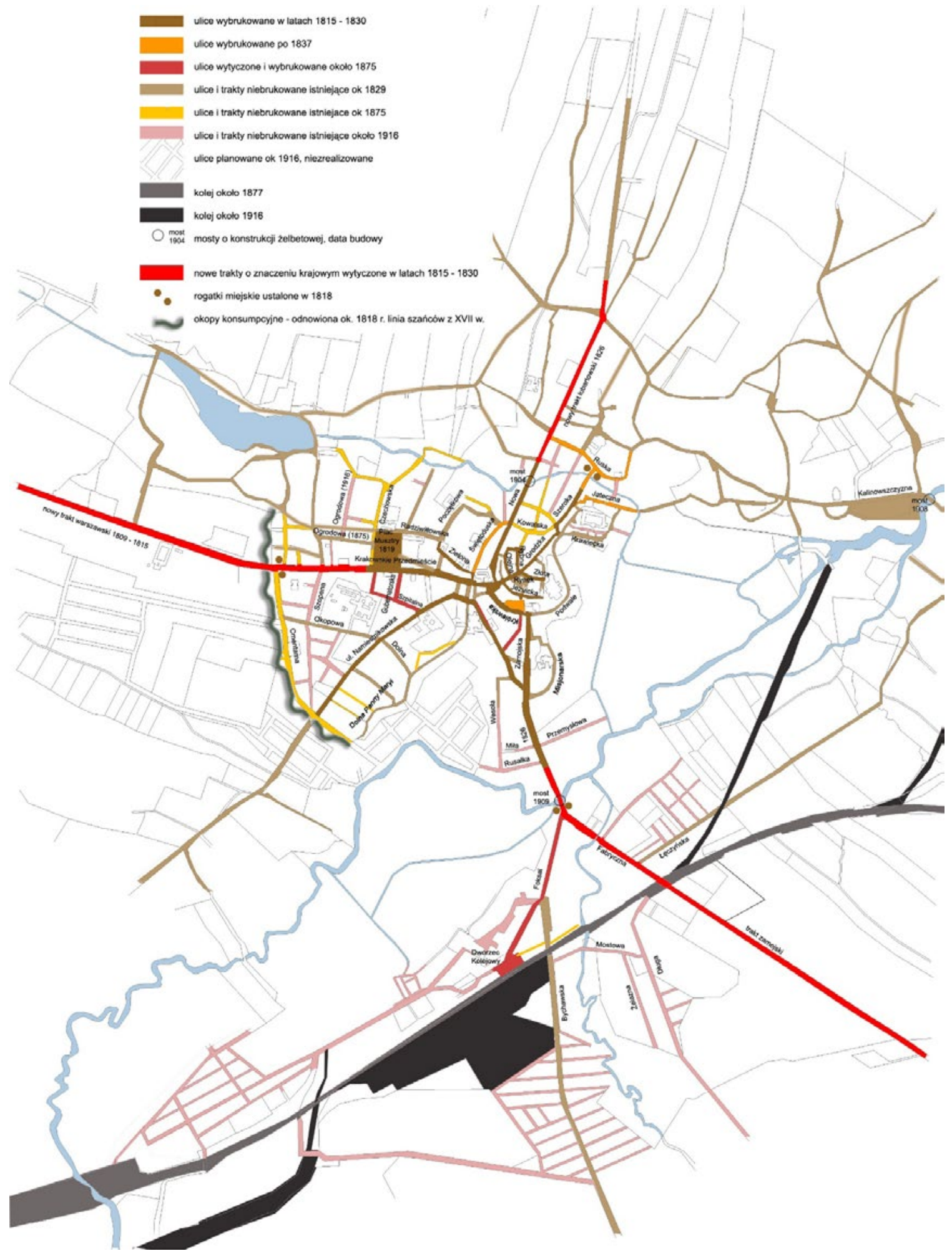

Fig. 5. The diagram of Lublin's transport system 1815-1916. Author: Natalia Przesmycka 


\section{Development of the southern part of the city}

The decision which had the greatest influence on the direction of Lublin's development at the end of the $19^{\text {th }}$ and $20^{\text {th }}$ century was the location of the railway station. The shape of the land, ownership status and regulations effective in the Russian Empire determined the choice of land in the suburbs of Piaski. This marked the beginning of a new southern direction of spatial development of Lublin. The buildings, with a dominant industrial function, first filled the area between the railway station and Zamojska Street, and later concentrated along the railway line, where large production plants were built. The factories were accompanied by workers' housing estates built in two ways: in the areas designated for it, with streets and allotments (e.g. Bronowice, side streets of the Bychawska Street, Za Cukrownią district), and spontaneous illegal buildings, on the periodically flooded meadows of the Bystrzyca River (Dzierżawna Street, Wapienna Street). These substandard buildings, intended as a temporary, have survived to the present day, preserved in the $20^{\text {th }}$ century after the construction of the Zemborzycki Reservoir and the regulation of the Bystrzyca River.

At the turn of the $19^{\text {th }}$ and $20^{\text {th }}$ century, Lublin started to develop spontaneously along its main communication arteries (roads and railway lines), thus adopting the model of a linear city. In the first years of the $20^{\text {th }}$ century the auxiliary and technical buildings along the railway line developed spontaneously. A railway bridge was built in 1907. By 1914, dense buildings along Bychawska Street reached the vicinity of Nowy Świat Street.

The spontaneous development of construction in the southern part of the city, on the right bank of Bystrzyca River - along the streets leading to Bychawa and Wrotków in the districts of Piaski, Bronowice and Kośminek, started in the last quarter of the $19^{\text {th }}$ century. In these districts the whole industry of the city was gradually concentrated. New factories were established in this area and those that were previously located in the city centre were relocated here. Along the railway line, industrial plants were set up: a sugar factory, rectification plants, a starch factory and associated banded housing; at Krochmalna and Bychawska Streets. These new districts were separated by railway tracks and the Czerniejówka River. Their buildings were initially chaotic and the districts did not have any communication links between them. The districts "behind the tracks" connected to the city centre with only one artery - Zamojska Street, which already a few years after the railway was put into operation became overloaded with traffic. Most of the investments made at that time were located within the range of the railway line, along the sidetracks. The main building bands in this area are the located along the railway line near Łęczyńska Street in Bronowice, where several larger warehouses were erected: the governmental spirit storehouse, liquid fuel storehouses (kerosene), grain warehouses, as well as along Krochmalna Street on the land of the former Bridgettines' Rury farm. The early twentieth century was a period of intensive development of the food industry. An important investment was the construction of a gasworks in 1879-1882, located near a railway station in Lublin's industrial district.

\section{Summary}

Difficulties in shaping new developments, resulting from land ownership status, previous courses of roads, communications tracts and particular topography contributed to the picturesque urban landscape of the city at the beginning of the $20^{\text {th }}$ century. The development of buildings in the direction of the city centre was prevented by wet, occasionally flooded meadows in the Bystrzyca River valley. Never again, these complex conditions constitute an obstacle to the development of the city, which of course was due to the development of engineering capabilities and legal instruments. In the 1920s and 1930s, the planners were already able to act with a broad scope, creating comprehensive plans for the "great Lublin" ${ }^{24}$. 


\section{References}

[1] Berdecka A., Lokacje i zagospodarowanie miast królewskich w Małopolsce za Kazmierza Wielkiego (1333-1370), W-wa, Kraków, Gdańsk, Łódź, Zakład Narodowy im. Ossolińskich. Wydawnictwo PAN, 1982.

[2] Ciołek G., Ogrody Lublina w XIX wieku, Ochrona Zabytków, rok 7, Warsaw 1954, nr 4.

[3] Gawarecki H., Stanisław Krzesiński: Dwa wrażenia, czyli Lublin jak byt w roku 1827 i jaki jest w roku 1877, [w:] Rocznik Lubelski, R. I, 1958, Lublin.

[4] Gawdzik Cz., Rozwój urbanistyczny Starego Lublina, Ochrona Zabytków, 7 (3)/26, 1954.

[5] Gazda L., Karaś S., Inż. Lutosławski i jego mosty w Lublinie, Drogownictwo, no. 2/2004, Warsaw.

[6] Ilustrowany przewodnik po Lublinie utożony przez Marię Antoninę hr. Ronikerowa, Warszawa 1901, p. 214.

[7] Kierek A., Rozwój gospodarczy Lublina w latach 1918-1939, [in:] Dzieje Lublina, Volume II, edited by S. Krzykała, Lublin 1975.

[8] Kociuba D., Przyrodnicze, gospodarcze i polityczne uwarunkowania rozwoju struktury przestrzennej Lublina, doctoral thesis, mps., UMCS, Lublin 2005.

[9] Kuprianowicz G., Roszczenko M., Cerkiew Prawosławna Przemienienia Pańskiego w Lublinie, Lublin 1993

[10] Kurzątkowski M., Materiaty do lubelskiej działalności M. Stompfa, [in:] Studia i materiały Lubelskie, T. VI, 1972.

[11] Mikulec B., Aktywność gospodarcze ludności żydowskiej Lublina w latach 1815-1864, [in:] Żydzi w Lublinie, Lublin 1995.

[12] Przesmycka N., Lublin przeobrażenia urbanistyczne 1815-1939, Lublin 2010.

[13] Rozwałka A., Niedźwiadek R., Stasiak M., Lublin wczesnośredniowieczny, Wyd. Trio, Lublin 2006.

[14] Studium Historyczno-Urbanistyczne do planu szczegółowego Śródmieście w Lublinie, mps WKZL, Lublin 1969.

[15] Tołwiński T., Urbanistyka, T. 1, Warsaw 1939

[16] Żywicki J., Architektura neogotycka na Lubelszczyźnie, Lublin 1998. 